\title{
A Geomagnetic Secular Variation Record for the Last Glacial Period, Reconstructed from Coastal Bog Sediments on the Inland Sea of Japan
}

\author{
Sumiyo Minemoto*1, Masayuki Hyodo*2 and Toshiro Naruse*3
}

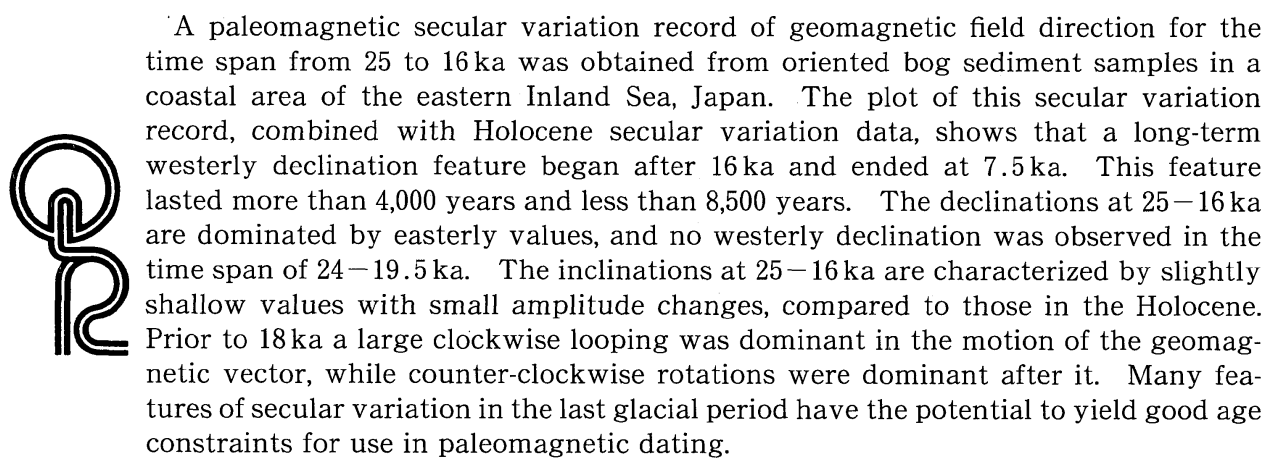

Key Words : Paleomagnetism, geomagnetic secular variation, the last glacial period, bog sediment

\section{Introduction}

Paleomagnetic study of sedimentary sequences yields continuous records of the geomagnetic field of the past, extending our knowledge of geomagnetic field behaviors and geodynamic processes. Most data on reversal transitions, excursions, and secular variations have been obtained from paleomagnetic records in marine and lacustrine sediments. Past geomagnetic field behavior can also be useful for dating. Recent paleomagnetic studies of lacustrine and shallow-marine sediment cores have yielded time scales based on geomagnetic secular variation (SV) in various regions (e.g., Hyodo et al., 1993 ; Lund, 1996).

In Japan, an SV record of geomagnetic field direction has been obtained by stacking data from large-diameter $(20 \mathrm{~cm})$ cores taken from lakes and the Inland Sea (Hyodo et al., 1993 ; Hyodo and Minemoto, 1996). This study has extended the time span of the SV record back to $11.6 \mathrm{ka}$, about six times that for archeomagnetic SV (Hirooka, 1971; Maenaka, 1990). There is presently no SV record prior to 11.6 ka constructed by stacking data from several sites.

The Holocene SV record in Japan has many prominent features that may be used for dating. One of these is the large westerly dec-

Received April 1, 1999. Accepted May 29, 1999.

*1 The Graduate School of Science and Technology, Kobe University. 1-1 Rokkodai, Nada-ku, Kobe 6578501, Japan. Present address : Itami Municipal Itami Senior High School. 4-1 Gyoki-cho, Itami, 664-0857, Japan.

*2 Research Center for Inland Seas \& Department of Earth and Planetary Sciences, Kobe University. 1-1 Rokkodai, Nada-ku, Kobe, 657-8501, Japan.

*3 Department of Geography, Hyogo University of Teacher Education. Yashiro-cho, Kato-gun, Hyogo Prefecture, 673-1494, Japan. 
lination swing that started before $11.6 \mathrm{ka}$ and persisted until $7.5 \mathrm{ka}$. The time when this westerly swing started is presently unknown. Large early Holocene westerly declinations have also been detected in homogeneous marine clay in Osaka Bay using hand-oriented samples (Muroi and Yaskawa, 1977 ; Hyodo and Yaskawa, 1986) and in a stalagmite from western Japan (Morinaga et al., 1992). Based on this information, the westerly swing is not an artifact of core twisting and/or core tilting, but a true geomagnetic signal. Determining exactly when this westerly declination swing began is important for magnetochronologic studies.

In this study, paleomagnetic fields have been reconstructed from hand-oriented samples of bog sediments formed during the last glacial period, and an SV record has been obtained for a time span of about 9,000 years. Characteristic features of the SV are discussed, along with similar features in the Holocene. Bog sediments have never been used for SV studies, but they were sometimes used for magnetostratigraphic studies, and yielded good quality paleomagnetic data (e.g., Qing and Zhou, 1991 ; Biswas et al., 1999).

\section{Geological setting and sampling}

The Ikari-iwa Lowland (Tanaka, 1997) near Mitsu Town, Hyogo Prefecture, is located about $2 \mathrm{~km}$ north from the shoreline of the Inland Sea of Japan (Fig. 1). It is bounded to the north and south by hills less than $200 \mathrm{~m}$ high, and to the east by the Ibo River. The basement rocks in the hills consist of late Cretaceous rhyolites. Marine terrace deposits along the shore of the Inland Sea near Mitsu Town, which intercalate with the Akahoya (KAh) tephra layer, show that sea level rose as much as $3.5-5 \mathrm{~m}$ higher than at present after $6.3 \mathrm{ka}$ (Naruse et al., 1985). This marine transgression did not reach the present study site $\left(34^{\circ} 47.5^{\prime} \mathrm{N}, 134^{\circ} 32.8^{\prime} \mathrm{E}\right)$, where bog sediments are exposed at an elevation of about $8 \mathrm{~m}$.

Paleomagnetic samples were taken from a section of sediments, about $4 \mathrm{~m}$ thick, that were deposited in a bog and exposed by agricultural activities. The conformable sequence of sediments consists mainly of horizontally layered

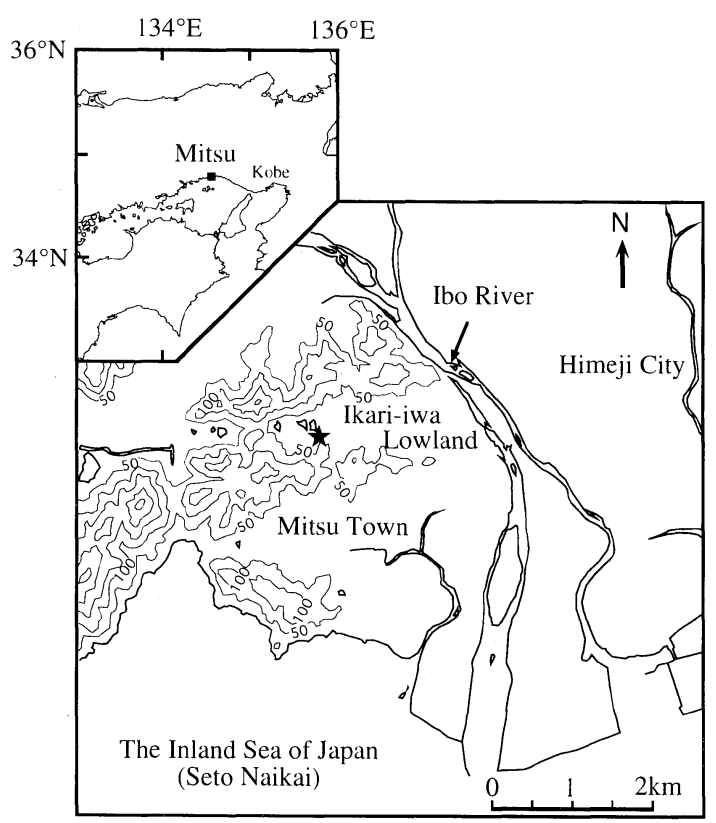

Fig. 1 Map showing sampling location

The star shows the sample site.

Table 1 Results of radiocarbon dating

\begin{tabular}{llcll}
\hline $\begin{array}{l}\text { Level } \\
(\mathrm{m})\end{array}$ & $\begin{array}{l}{ }^{14} \mathrm{C} \text { dates } \\
\text { (years BP) }\end{array}$ & $\begin{array}{l}\text { Calibrated dates } \\
\text { (calendar years) }\end{array}$ & $\begin{array}{l}\text { Sample } \\
\text { material }\end{array}$ & $\begin{array}{l}\text { Laboratory* } \\
\text { Code No. }\end{array}$ \\
\hline 1.00 & $16100 \pm 300$ & 18900 & humus & KEEA-80 \\
3.22 & $22500 \pm 225$ & 25800 & peat & KEEA-81 \\
\hline
\end{tabular}

*Kyushu Environmental Evaluation Association (KEEA)

Dating method: benzene synthesis - liquid scintillation counting Calibration is based on the varying oceanic circulation model by Laj et al. (1996) (see text).

fine-grained, peaty clay, clay and silt (Fig. 3), with an amphibolite-rich tephra layer (Naruse et al., 1995) in its upper part. We have determined two radiocarbon dates in this sequence (Table 1), the first being $16,100 \pm 300$ yr $1.00 \mathrm{~m}$ below the top of the section and just below the tephra layer, and the second being $22,500 \pm 40$ yr $3.22 \mathrm{~m}$ below the top. These dates suggest that the tephra layer correlates with the Sambe Ukinuno pumice fall deposit (U2, SUP : Miura and Hayashi, 1991) or the Sambe Ukinuno pyroclastic flow deposit (U 1: Matsui and Inoue, 1971). The age of the U 2 tephra has been estimated at $15-16 \mathrm{ka}$ (Matsui and Inoue, 1971) and $15.8 \mathrm{ka}$ (Nomura et al., 1995), and the 
age of the U 1 tephra at $15.6 \mathrm{ka}$ (Katoh et al., 1996). Naruse et al. (1995) suggested that the Aira-Tn (AT) tephra of $24.3 \mathrm{ka}$ age (Murayama et al., 1993) should be present below the bottom of the section, and this tephra was found by trenching about $30 \mathrm{~m}$ to the north and about 1 $\mathrm{m}$ below the bottom of the main section we sampled.

The procedure for hand-sampling is as follows : First, an excavation was made to a depth of $10-20 \mathrm{~cm}$ below the outcrop surface, and a horizontal surface was made in fresh sediments with non-magnetic tools. Second, a brass guide was fixed to the flat surface, and the azimuth and plunge of the guide were measured. Third, titanium tubes $5 \mathrm{~cm}$ long and $2.5 \mathrm{~cm}$ wide were forced into the sediment along the guide by blows of a plastic hammer. The guide and tubes were then taken off and the sediment sample in the titanium tube was carefully transferred into a cubic polycarbonate capsule with a volume of $10 \mathrm{~cm}^{3}$, using a tool with a titanium piston. To prevent drying, the cubic capsules were immediately sealed with a plastic bonding agent.

A total of 135 paleomagnetic samples from 28 horizons were collected, mainly from finegrained sediments. All samples were stored in hermetically sealed cases with wet tissue paper to keep them moist, and measured in three weeks.

\section{Conversion to a time scale}

The vertical scale for the section was converted to a time scale using the two radiocarbon dates. The dates of 16.1 and $22.5 \mathrm{ka}$ were corrected to 18.9 and $25.8 \mathrm{ka}$, respectively, using a geomagnetic calibration that is based on geomagnetic intensity and assuming a varying oceanic circulation model (Laj et al., 1996). At present, we consider the geomagnetic calibration of Laj et al. (1996) to be the best available for the last $50 \mathrm{kyr}$, especially for studies beyond the range of dendrochronology (Stuiver and Reimer, 1993 ; Kromer and Becker, 1994). These calibration data are generally consistent with those from tree-ring calibration (Stuiver and Reimer, 1993 ; Kromer and Becker, 1994), varve calibration (Goslar et al., 1995) and U-Th calibration (Bard et al., 1990,
1993 ; Edwards et al., 1993).

Each sampling level was dated by liner interpolation between the dated levels at 1.00 and $3.22 \mathrm{~m}$, and extrapolated above $1.00 \mathrm{~m}$ using the accumulation rate of $32 \mathrm{~cm} / \mathrm{kyr}$ calculated for the sequence below $1.00 \mathrm{~m}$. There is no clear evidence to support the assumption of constant sedimentation, but the absence of evidence for a hiatus, less sand, and the almost constant susceptibility (except for the tuff layer), may support this assumption. The average accumulation rate of $32 \mathrm{~cm} / \mathrm{kyr}$ is much lower than the rates seen in Holocene lake and shallow-marine sediments in Japan, such as 130 $\mathrm{cm} / \mathrm{kyr}$ in Lake Kizaki, $83 \mathrm{~cm} / \mathrm{kyr}$ in Lake Yogo (Hyodo et al., 1993), and $90-150 \mathrm{~cm} / \mathrm{kyr}$ in Osaka Bay (Takatsugi and Hyodo, 1995). However, this rate is consistent with those from bog sediments of the last glacial period. For example, accumulation rates are estimated to be $26 \mathrm{~cm} / \mathrm{kyr}$ at Hosoike Moor, western Japan (Nomura et al., 1995), and $25 \mathrm{~cm} / \mathrm{kyr}$ in Fusedame Pond, central Japan (Matsushita and Maeda, 1996).

\section{Magnetic measurements and results}

Natural remanent magnetization (NRM) was measured using a $2 \mathrm{G}$ super-conducting rock magnetometer, and a tumbler-type Natsuhara alternating field demagnetizer was used for demagnetization. Low-field magnetic susceptibility was measured using a Bartington susceptibility meter.

NRM intensities range from $0.54-4.61 \times 10^{-3}$ $\mathrm{Am}^{-1}$, and susceptibility values range from 6.6 $-25 \times 10^{-5}$ SI except for samples from the tephra layer. The samples that contain tephra materials have an average NRM intensity of $8.3 \times 10^{-3} \mathrm{Am}^{-1}$ and an average susceptibility of $61.2 \times 10^{-5}$ SI. These measurements are listed in Table 2, together with other magnetic results.

All specimens were subjected to progressive demagnetization in alternating fields (AF). They were first demagnetized at levels of $2.5,5$, 7.5 , and $10 \mathrm{mT}$, and subsequent demagnetization levels were then selected depending on the degree of intensity decrement. Usually we adopted four to ten steps at levels of $15,20,25,30$, $40,50,60,80,100$, and $120 \mathrm{mT}$. Median destruc- 
Table 2 Results of magnetic measurements

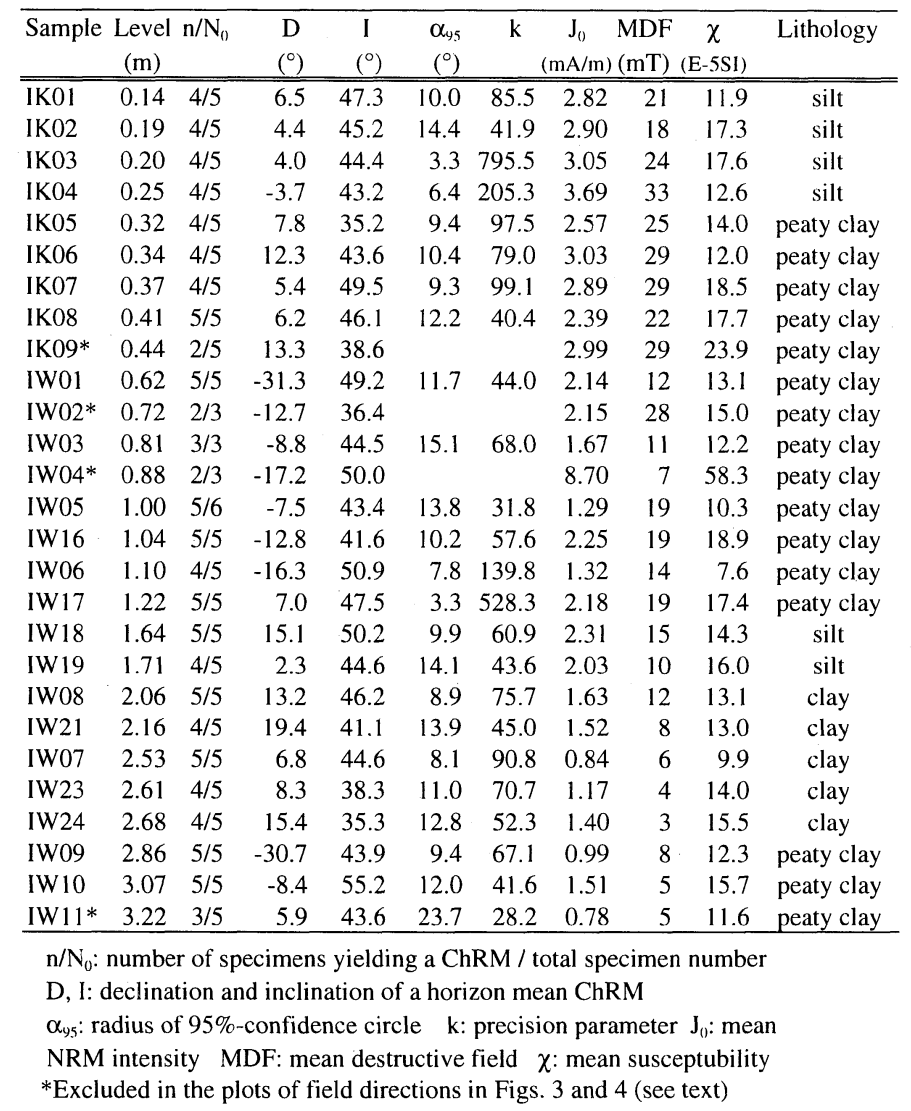

tive fields (MDF), at which the NRM intensity decreases to half the original value, ranged from 3 to $33 \mathrm{mT}$ and were $16 \mathrm{mT}$ on average.

Most of the samples have stable NRMs, as shown in the results of AF demagnetization in Figure 2. A weak viscous magnetization component was removed by demagnetization at an AF level lower than $7.5 \mathrm{mT}$. Characteristic remanent magnetizations (ChRM) were calculated for 110 clay or silt samples by principal component analysis (Kirschvink, 1980). ChRMs were not calculated for 25 samples, most of which except five coarse silt ones have lower MDFs $<5 \mathrm{mT}$ or lower NRM intensities compared with other samples in the same horizon. The sediment structure of these samples may have been disturbed during the sampling procedure. The unstable NRMs of coarse silt samples, from which no ChRM was isolated, may be caused by coarse magnetic grains. No ChRM was obtained at one horizon. We did not observe any difference in magnetic properties between organic and inorganic sediments. However, we find that the MDF tends to increase upward, while the magnetic susceptibility shows relatively uniform values from the base to the top (Fig. 3). This MDF change may indicate the increase of fine-grained magnetic minerals, caused by a gradual climate change or some other factors of paleoenvironment during the last glacial period.

The mean paleomagnetic direction was calculated for each horizon based on the ChRMs. The mean declination and inclination at 23 horizons, excluding those with an asterisk in Table 2, are shown in Figure 3. Four horizons with an asterisk in Table 2 either show a large scattering or yielded no statistical parameters, but they are consistent with the plotted directions.

Both the declination and inclination exhibit small amplitudes of change (Fig. 3). A notable 

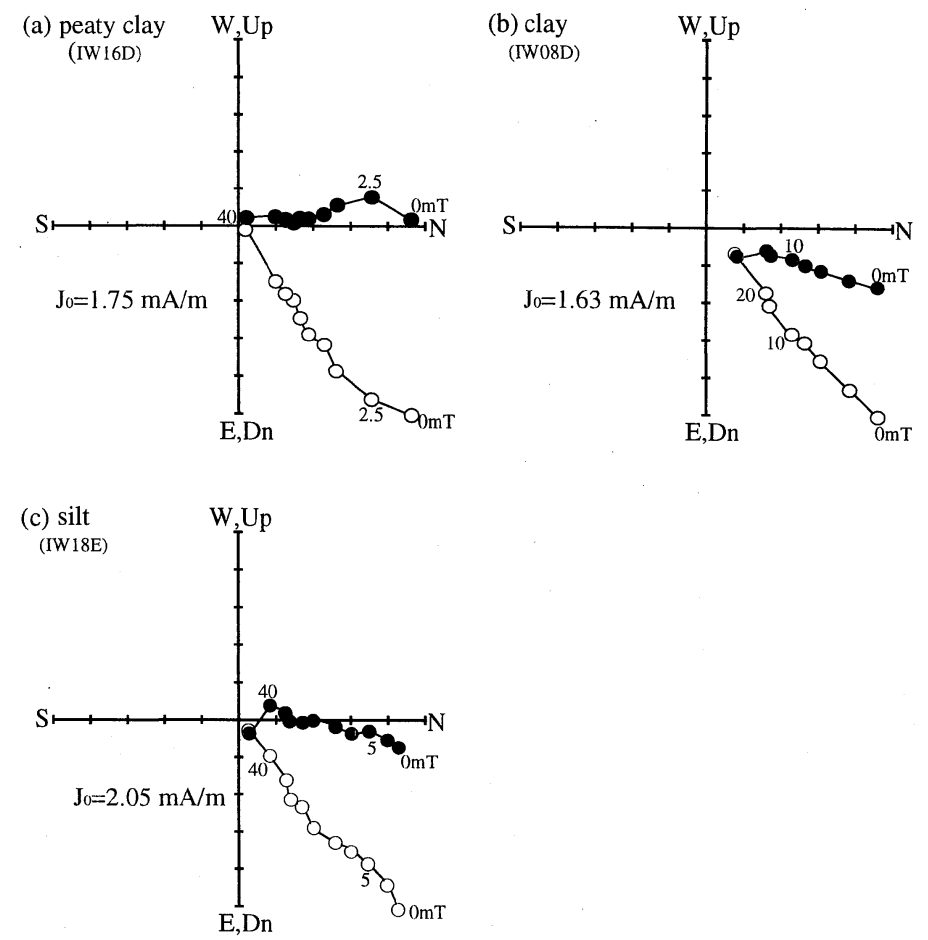

Fig. 2 Representative results from progressive AF demagnetization of samples of peaty clay (a), clay (b), and silt (c)

Solid and open circles show projections on the horizontal and vertical planes, respectively.

feature is that easterly declination is dominant, especially in the $2.7-1.2 \mathrm{~m}$ interval. The declination also evidences a long-term sinusoidal change.

Declination and inclination for the mean of average directions at all horizons are $1.1^{\circ}$ and $45.6^{\circ}$, respectively. The inclination is shallower than that expected from the geocentric axial dipole, which is $54.3^{\circ}$. This shallow inclination does not reflect the inclinationshallowing in magnetization process. Postdepositional detrital magnetization is acquired along with the ambient magnetic field (Irving and Major, 1964), as has been verified in many laboratory experiments (e.g., Tucker, 1980; Otofuji and Sasajima, 1981) and by numerous paleomagnetic observations. No systematic inclination error has been found in Holocene $\mathrm{SV}$ records that are comparable to the SV from archeomagnetism (Turner and Thompson, 1981 ; Hyodo et al., 1993), or from lava flows
(Lund, 1985). Inclination-shallowing due to compaction during diagenesis (Blow and Hamilton, 1978 ; Anson and Kodama, 1987 ; Arson and Levi, 1990) is also implausible because the bog sediments in Ikari-iwa Lowland have scarcely acquired overlying deposits following the last glacial. A shallow inclination during the last glacial period has also been observed in Pacific deep-sea sediments off Shikoku Island (Ohno et al., 1993).

\section{Discussion}

\section{Geomagnetic secular variation}

The paleomagnetic field directions obtained in this study range from 25 to $16 \mathrm{ka}$ in calendar years. These data are plotted in Figure 4, together with the Holocene SV record obtained in an area from central to southwestern Japan (Hyodo et al., 1993). The time scale in conventional radiocarbon years is also shown on the right in Figure 4. 


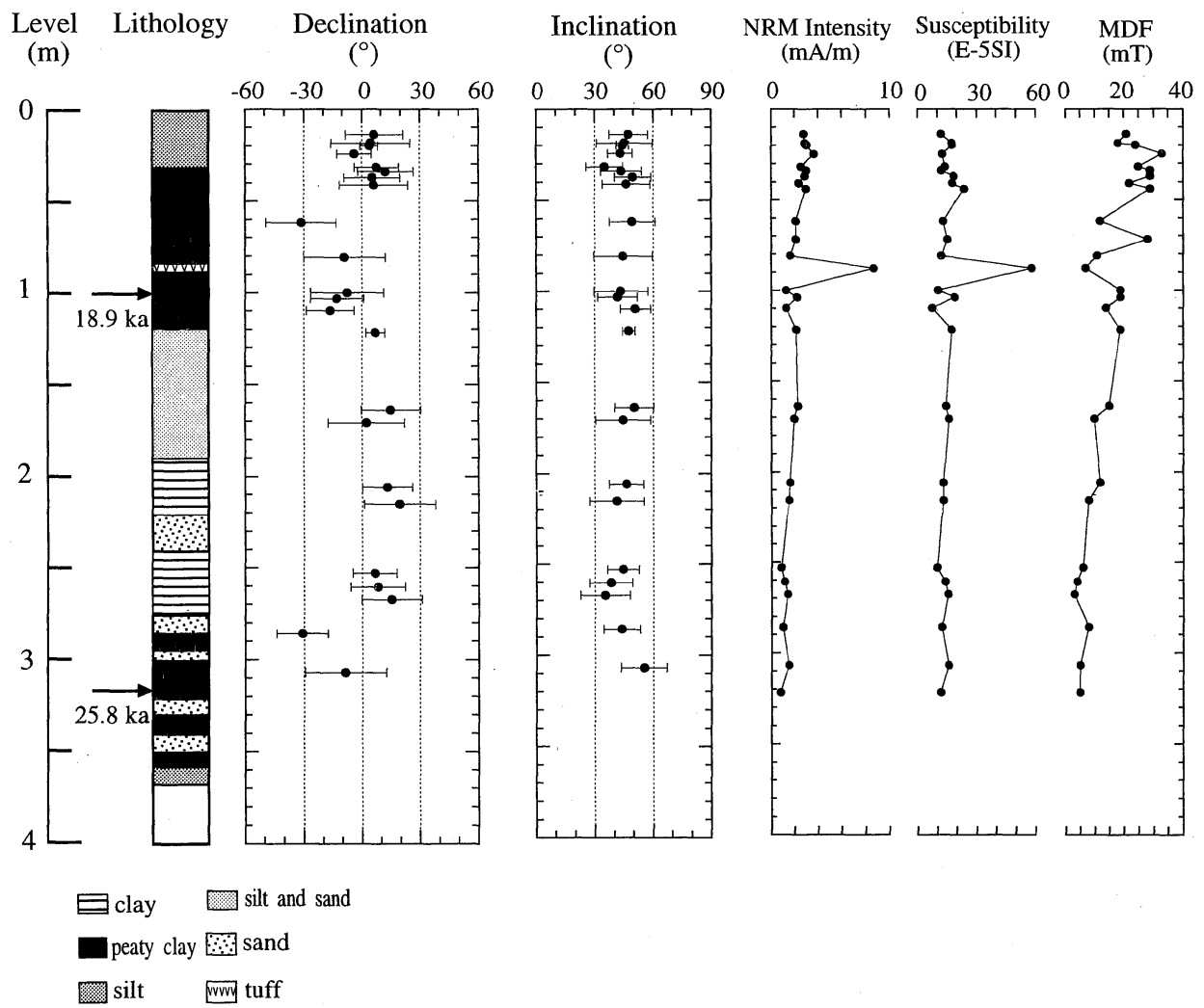

Fig. 3 Lithology, paleomagnetic field directions, NRM intensity, susceptibility, and MDF from the Ikari-iwa Lowland near Mitsu Town, southwestern Japan

The two arrows in the lithology show horizons dated by the radiocarbon method. The calibrated age data are shown. In the declination and inclination plots, the solid circles show the mean of characteristic remanent magnetizations at each horizon, and the error bars represent limits of a 95\%confidence circle. The magnetic data in the right three plots show the horizon mean values listed in Table 2.

The declination plot represents a cluster of values of about $5^{\circ} \mathrm{E}$ at $17-16 \mathrm{ka}$. The easterly declination in this period suggests that the long-term westerly declination swing that persisted until $7.5 \mathrm{ka}$ in the early Holocene began after $16 \mathrm{ka}$, and that the time span of this westerly swing was 8,500 years at most. Before $17 \mathrm{ka}$, the westerly declination period and easterly declination period seem to alternate, although the latter period is longer. The long interval of easterly declination at $24-19.5$ ka (Fig. 5) may be a useful age constraint.

The inclinations during the time span 25-16 ka change within a narrow range from $35-55^{\circ}$, but mostly between 40 and $50^{\circ}$ (Fig. 4). Another salient feature is that there are no incli- nation data steeper than $60^{\circ}$. Thus, the inclinations of paleomagnetic fields during the last glacial period were characterized by slightly shallow values with small amplitude changes.

For comparison, the paleomagnetic field direction at the time of the AT ash fall, calculated from the paleomagnetic chart of Nakajima and Fujii (1995), is also plotted in Figure 4. An age of $27.8 \mathrm{ka}$ in calendar years is used for the AT tephra data, calibrated in the same way. The paleomagnetic direction is consistent with the features of the SV at $25-16 \mathrm{ka}$.

\section{Field vector motion}

The motion of the geomagnetic field vector in the Bauer plot in Figure 5 is characterized by elongated fluctuations confined to an east- 


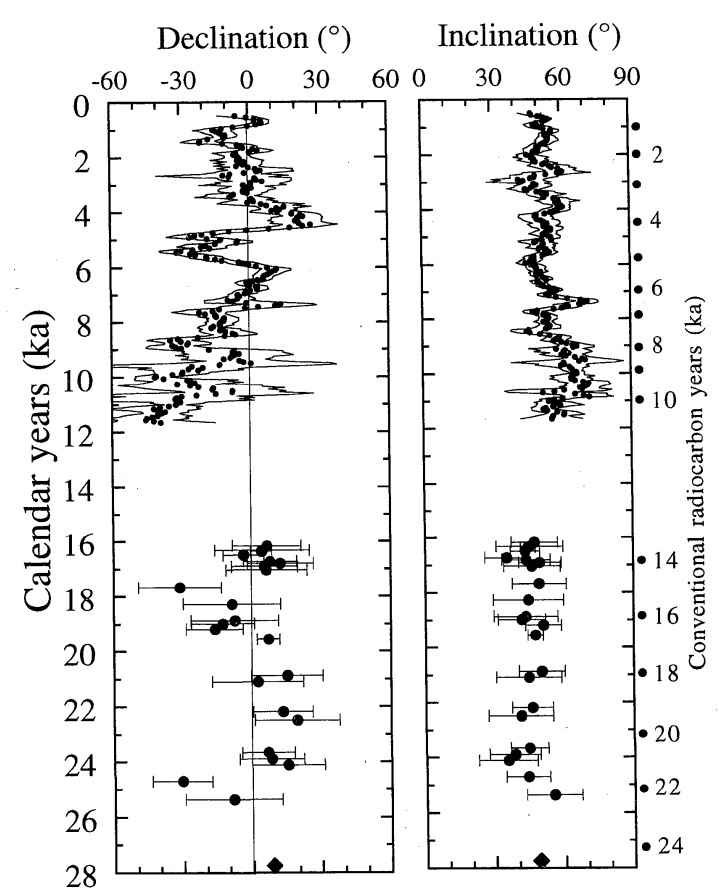

Fig. 4 Combined plot of geomagnetic secular variation data for southwestern Japan since $28 \mathrm{ka}$

The data in this study are plotted for $25.5-16 \mathrm{ka}$. The error bars show limits of a $95 \%$-confidence circle. SVJ 1 data (Hyodo et al., 1993) are for the time span 11.6-0.5 ka. The dots show mean directions for each 50-yr interval, and the thin lines represent a $95 \%$-confidence circle. The diamond shows a paleomagnetic direction at the time of the AT ash fall, calculated from the magnetic chart of Nakajima and Fujii (1995).

west direction throughout the time span of 25 $-16 \mathrm{ka}$. This is caused by high-amplitude changes in declination, relatively to the inclination values. There was clearly a change in the sense of rotational motion at about $18 \mathrm{ka}$. The field vector was dominated by clockwise motion before $18 \mathrm{ka}$, and by counter-clockwise motions after $18 \mathrm{ka}$. The large clock wise looping motion seen in Figure 5 -a has a period of about 5,000 years, which is much longer than the period of $1,000-1,300$ years, the estimate of dominant periodicity for clockwise rotation during Holocene time in Britain, North America, and Australia (Itota et al., 1997). It is also longer than the period of $2,100-2,400$ years, the estimate in Japan (Itota et al., 1992) and (a) $25-18 \mathrm{ka}$

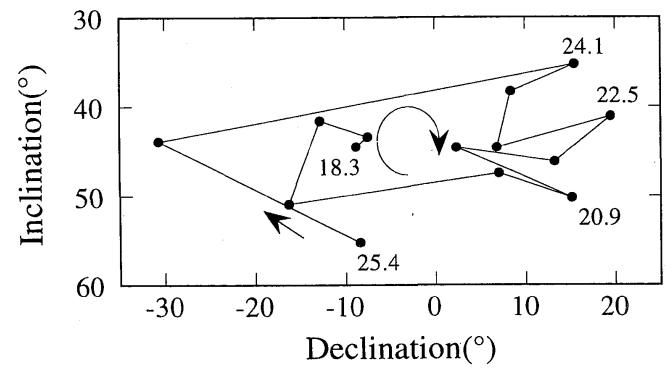

(b) $18-16 \mathrm{ka}$

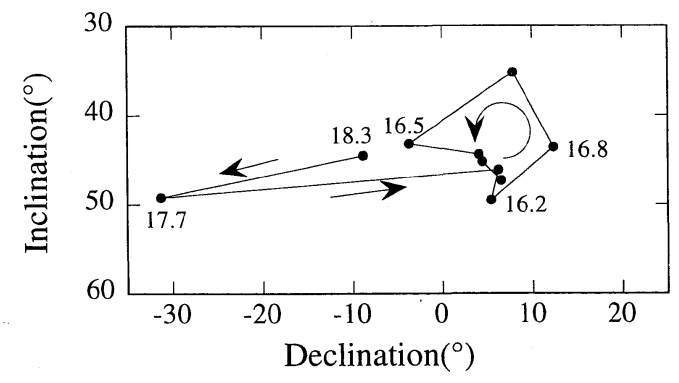

Fig. 5 Bauer plots of the paleomagnetic field directions from the Ikari-iwa Lowland at 25-18 ka (a) and 18-16 ka (b)

The ages are in calendar years. The arrows show forward direction in time.

Britain (Itota et al., 1997). Only in North America has a period of clockwise field motions as long as 5,600 years been estimated for the Holocene (Itota et al., 1997). This agreement in the sense of rotation and the similar periods may indicate a causal relationship.

According to Runcorn's rule (Runcorn, 1959 ; Skiles, 1970), clockwise vector motions are generated by westward drift of a non-dipole magnetic field. If this rule is applied to the clockwise rotational period of about 5,000 years obtained in this study, then there was an estimated westward drift of the non-dipole field of about $0.07^{\circ} / \mathrm{yr}$. This rate is significantly slower than $0.36^{\circ} / \mathrm{yr}$, the rate estimated by Yukutake (1967) from historical records of observation, and is about half of the $0.13^{\circ} / \mathrm{yr}$ estimated from Holocene data (Hyodo et al., 1993). Quite different sources may have caused such different rates for westwarddrifting fields. Counter-clockwise rotations were dominant after $18 \mathrm{ka}$ (Fig. 5), which may have been due to the eastward drifting of non- 
dipole fields. Such a change in the sense of field vector rotation may become a useful age constraint, in addition to providing important geophysical insights.

A number of features in the geomagnetic SV of the last glacial period have the potential for yielding good age constraints in paleomagnetic dating. However, it will be necessary to accumulate more such data with reliable age constraints in order to develop the SV record into a dependable dating tool. In SV studies, using oriented sediment samples is superior to using bored cores that are easily affected by coretilting and inaccurate horizontal orientation. In this regard, the data obtained in this study are particularly valuable. So far, reconstruction of paleomagnetic fields from oriented sediment samples is quite few (e.g., Turner et al., 1982). This method will be important for future SV studies.

\section{Conclusions}

Paleomagnetic measurements of oriented samples from coastal bog sediments in the eastern Inland Sea, Japan, yield a paleomagnetic SV record for the $25-16 \mathrm{ka}$ time span. A plot of the SV data combined with published data for the Holocene shows that a long-term westerly declination swing began after $16 \mathrm{ka}$ and ended at $7.5 \mathrm{ka}$. The time span of the westerly declination swing was longer than 4,000 years and shorter than 8,500 years. The following SV features useful for dating are found in the 25-16 ka time span: The declinations are dominated by easterly values; easterly declination was maintained, especially at $24-19.5$ $\mathrm{ka}$; the inclinations are characterized by slightly shallow values, with small amplitude changes, ranging mainly from 40 to $50^{\circ}$; the motion of the geomagnetic vector is elongated in an east-west direction; the sense of rotational motion clearly changed at about $18 \mathrm{ka}$. A large clockwise looping motion was dominant prior to $18 \mathrm{ka}$, while counter-clockwise rotations became dominant afterwards.

\section{Acknowledgments}

We wish to thank M. Torii for valuable comments, and T. Kawasaki for his analyses of volcanic ash. We greatly appreciate K. Uno,
R. Enami, M. Kaneko and T. Murakami for assistance in sampling.

\section{References}

Anson, G.L. and Kodama, K.P. (1987) Compactioninduced inclination shallowing of the postdepositional remanent magnetization in a synthetic sediment. Geophys. J. R. astr. Soc., 88, 673-692.

Arason, P. and Levi, S. (1990) Compaction and inclination shallowing in deep-sea sediments from the Pacific Ocean. J. Geophys. Res., 95, 4501-4510.

Bard, E., Hamelin, B., Fairbanks, R.G. and Zindler, A. (1990) Calibration of the ${ }^{14} \mathrm{C}$ timescale over the past 30,000 years using mass spectrometric $\mathrm{U}-\mathrm{Th}$ ages from Barbados corals. Nature, 345, 405-410.

Bard, E., Arnold, M., Fairbanks, R.G. and Hamelin, B. (1993) ${ }^{230} \mathrm{Th}^{-234} \mathrm{U}$ and ${ }^{14} \mathrm{C}$ ages obtained by mass spectroscopy on corals. Radiocarbon, 35, 191-199.

Biswas, D.K., Hyodo, M., Taniguchi, Y., Kaneko, M., Katoh, S., Sato, H., Kinugasa, Y. and Mizuno, K. (1999) Magnetostratigraphy of Plio-Pleistocene sediments in a 1700-m core from Osaka Bay, southwestern Japan and short geomagnetic events in the middle Matuyama and early Brunhes chrons. Paleogeography, Pleoclimatology, Paleoecology, 148, 233-248.

Blow, R.A. and Hamilliton, N. (1978) Effect of compaction on the acquisition of a derital remanent magnetization in fine-grained sediments. Geophys. J. R. astr. Soc., 52, 13-23.

Edwards, R.L., Beck, J.W., Burr, G.S., Donahue, D.J., Chappell, J.M.A., Bloom, A.L., Druffel, E.R.M. and Taylor, F.W. (1993) A large drop in atmospheric ${ }^{14} \mathrm{C}$ $/{ }^{12} \mathrm{C}$ and reduced melting in the Younger Dryas, documented with ${ }^{230} \mathrm{Th}$ ages of corals. Science, 260 , 962-968.

Goslar, T., Arnold, M., Bard, E., Kuc, T., Padzur, M.F., Ralska-Jasiewiczowa, M., Rozanski, K., Tisnerat, N., Walanus, A., Wicik, B. and Wiekowski, K. (1995) High concentration of atmospheric ${ }^{14} \mathrm{C}$ during the Younger Dryas cold episode. Nature, 377, 414-417.

Hirooka, K. (1971) Archaeomagnetic study for the past 2,000 years in southwest Japan. Mem. Fac. Sci., Kyoto Univ., 38, 167-207.

Hyodo, M. and Yaskawa, K. (1986) Palaeomagnetism of a core sediment from the Inland Sea, Japan (Seto Naikai). J. Geomag. Geoelectr., 86, 41-56.

Hyodo, M., Itota, C. and Yaskawa, K. (1993) Geomagnetic secular variation reconstructed from magnetizations of wide-diameter cores of Holocene sediments in Japan. J. Geomag. Geoelectr., 45, 669-696.

Hyodo, M. and Minemoto, S. (1996) Paleomagnetic dating using geomagnetic secular variation and excursions from lake sediments in Japan. The Quat. Res. (Daiyonki-Kenkyu), 35, 125-133. (J+E)

Irving, E. and Major, A. (1964) Post-depositonal detrital remanent magnetization in a synthetic sediment. Sedimentology, 3, 135-143. 
Itota, C., Hyodo, M. and Yaskawa, K. (1992) Separation of paleomagnetic secular variation components : a method and its application to a sedimentary record from Japan. J. Geomag. Geoelectr., 44, 943-957.

Itota, C., Hyodo, M. and Yaskawa, K. (1997) Long-term features of drifting and standing nondipole fields as determined from Holocene palaeomagnetic secular variations. Geophys. J. Int., 130, 390-404.

Katoh, S., Danhara, T., Yamashita, T., Takemura, K. and Okada, A. (1996) Late Quaternary tephra layer derived from Sambe Volcano discovered in Kobe city, western Japan. The Quat. Res. (DaiyonkiKenkyu), 35, 383-389. (J)

Kirschvink, J.L. (1980) The least-squares line and plane and the analysis of paleomagnetic data. Geophys. J. R. astr. Soc., 62, 699-718.

Kromer, B. and Becker, B. (1994) Tree-ring calibration of the radiocarbon time scale back to 11,600 B.P. Radiocarbon, 37, 125-135.

Laj, C., Mazaud, A. and Duplessy, J.-C. (1996) Geomagnetic intensity and ${ }^{14} \mathrm{C}$ abundance in the atmosphere and ocean during the past $50 \mathrm{kyr}$. Geophys. Res. Lett., 23, 2045-2048.

Lund, S.P. (1985) A comparison of the statistical secular variation recorded in some late Quaternary lava flows and sediments, and its implications. Geophys. Res. Lett., 12, 251-254.

Lund, S.P. (1996) A comparison of Holocene paleomagnetic secular variation records from North America. J. Geophys. Res., 101, 8007-8024.

Maenaka, K. (1990) Archeomagnetic secular variation in South West Japan. Rock Mag. Paleogeophys., 17, 21-25.

Matsui, S. and Inoue, T. (1971) Volcanic deposites and stratigraphy from Mt. Sambe. Earth Science, 25, 147-163. (J)

Matsushita, M. and Maeda, Y. (1996) The last glacial and postglacial pollen assemblages at Fusedame Pond, south-eastern part of Ohmi Basin, Japan. Jpn. J. Histor. Bot., 4, 35-40. (J+E)

Miura, K. and Hayashi, M. (1991) Quaternary tephra studies in the Chugoku and Shikoku Districts. The Quat. Res. (Daiyonki-Kenkyu), 30, 339-351. (J+E)

Morinaga, H., Horie, I. and Yaskawa, K. (1992) A geomagnetic reversal recorded in a stalagmite collected in western Japan. J. Geomag. Geoelectr., 44, 661675.

Murayama, M., Matsumoto, E., Nakamura, T., Okamura, M., Yasuda, H. and Taira, A. (1993) Reexamination of the eruption age of Aira-Tn Ash (AT) obtained from a piston core off Shikokudetermined by AMS ${ }^{14} \mathrm{C}$ dating of planktonic forminifera-. Jour. Geol. Soc. Japan., 99, 787-798. (J+E)

Muroi, I. and Yaskawa, K. (1977) Paleomagnetism of Osaka Bay sediments. Rock Mag. Paleogeophys., 4, 76-80.

Nakajima, T. and Fujii, J. (1995) Paleomagnetic directions of the Aira Tn tephra deposits. The Quat. Res.
(Daiyonki-Kenkyu), 34, 297-307. (J+E)

Naruse, T., Onoma, M. and Murakami, Y. (1985) Some data on the Holocene sea-level changes in Harimanada, the Seto Inland Sea. Bull. Hyogo Univ. Teacher Education, 5, 53-64.

Naruse, T., Shiomi, R., Samizo, O. and Nakagawa, T. (1995) Reconstruction of physical environments at Ikariiwa-Minamiyama ancient site in Mitsu, Hyogo. Report of Mitsu Town Maizo Bunkazai, 1, 3768. (J)

Nomura, R., Tanaka, S., Kashiwaya, K., Soma, H., Ogura, H. and Kawasaki, T. (1995) Stratigraphic and petrographic properties of the tephra layers in Hosoike Moor, Okayama Prefecture, Japan. The Quat. Res. (Daiyonki-Kenkyu), 34, 1-8. (J+E)

Ohno, M., Hamano, Y., Murayama, M., Matsumoto, E., Iwakura, H., Nakamura, T. and Taira, A. (1993) Paleomagnetic record over the past 35,000 years of a sediment core from off Shikoku, southwest Japan. Geophys. Res. Lett., 20, 1395-1398.

Otofuji, Y. and Sasajima, S. (1981) A magnetization process of sediments : Laboratory experiments on post-depositionl remanent magnetization. Geophys. J. Roy. astr. Soc., 66, 241-259.

Qing, F. and Zhou, G. (1991) Quaternary geology and paleoanthropology of Yuanmou, Yunnan, China. 222 p, Science Press, Beijing.

Runcorn, S.K. (1959) On the theory of the geomagnetic secular variation. Ann. Geophys., 15, 87-92.

Skiles, D.D. (1970) A method of inferring the direction of drift of the geomagnetic field from paleomagnetic data. J. Geomag. Geoelectr., 22, 441-462.

Stuiver, M. and Reimer, P.J. (1993) Extended ${ }^{14} \mathrm{C}$ data base and revised calib $3.0{ }^{14} \mathrm{C}$ age calibration program. Radiocarbon, 35, 215-230.

Takatsugi, K.O. and Hyodo, M. (1995) A geomagnetic excursion during the late Matuyama Chron, the Osaka Group, southwest Japan. Earth Planet. Sci. Lett., 136, 511-524.

Tanaka, S. (1997) Topography and rock constituents. Yagi, T. (ed.) The history of Mitsu Town (Mitsuchoshi) : 3, 1-10, Mitsu Town. (J)

Tucker, P. (1980) A grain mobility model of postdepositional realignment. Geophys. J. R. astr. Soc., 63, 149-163.

Turner, G.M. and Thompson, R. (1981) Lake sediment record of the geomagnetic secular variation in Britain during Holocene times. Geophys. J. R. astr. Soc., 65, 703-725.

Turner, G.M., Evans, M.E. and Hussin, I.B. (1982) A geomagnetic secular variation study (31000$19500 \mathrm{bp}$ ) in Western Canada. Geophys. J. R. astr. Soc., 71, 159-171.

Yukutake, T. (1967) The westward drift of the earth's magnetic field in historic times. J. Geomag. Geoelectr., 19, 103-116.

$(\mathrm{J}+\mathrm{E})$ in Japanese with English abstract, $(\mathrm{J})$ in Japanese. 


\title{
瀬戸内海沿岸域の湿原堆積物から得られた 最終水期の地磁気永年変化
}

\author{
峯 本 須美代*1 - 兵 頭 政 幸*2 成 瀬 敏 郎*3
}

（要旨）

瀬戸内海東部における湿原堆積物の定方位試料から 25 16 ka の地磁気永年变化記録を得た. 完新世の地磁 気永年変化デー夕と合わせてプロットすると, これまで 報告されていた完新世以前から $7.5 \mathrm{ka}$ まで継続する長 期の偏角西振りの開始時期は $16 \mathrm{ka}$ 以降であること, お よびその西振り期間は 4,000 年以上, 8,500 年以下であ ることがわかった．期間 $25 \sim 16 \mathrm{ka}$ の偏角は, 東振りが
卓越している. 特に $24 \sim 19.5 \mathrm{ka}$ の間は, 西振り偏角が 観測されていない。期間 25〜16 ka の伏角は, 完新世に 比べやや低伏角で, 変動幅が小さい. 地磁気べクトルの 運動は, 約 $18 \mathrm{ka}$ 以前は大きな時計回り回転が卓越し, それ以降は半時計回りが卓越する. 最終氷期の地磁気永 年変化の多くの特徵は, 年代決定に使える可能性があ る.

${ }^{* 1}$ 神戸大学大学院自然科学研究科 $\overline{\mathbf{T}} 657-8501$ 神戸市灘区六甲台町 1-1. 現住所 : 伊丹市立伊丹高校 $\overline{\mathbf{T}} 664-0857$ 伊丹市行基町 4-1.

*2 神戸大学内海域機能教育研究センター・理学部地球惑星学科 †657-8501 神戸市灘区六甲台町 1-1.

*3 兵庫教育大学社会系 $\mathbf{T} 673-1494$ 兵庫県加東郡社町下久米. 